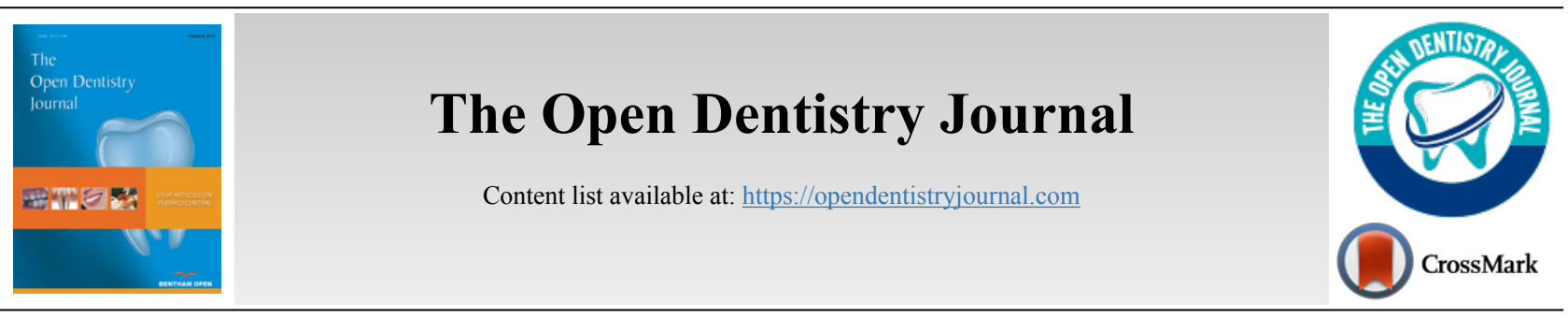

RESEARCH ARTICLE

\title{
Satisfaction with Orthodontic Care Provided in a University Orthodontic Clinic
}

\author{
Ioannis Lyros $^{1, *}$, Elpida Pavi ${ }^{2}$, Apostolos I. Tsolakis ${ }^{1}$, Margarita Makou ${ }^{1}$ and John Kyriopoulos ${ }^{2}$ \\ ${ }^{\prime}$ Department of Orthodontics, School of Dentistry, University of Athens, Athens, Greece \\ ${ }^{2}$ Department of Health Economics, National School of Public Health, Athens, Greece
}

\begin{abstract}
:
Objective:

To evaluate patients' satisfaction with their orthodontic care at the Department of Orthodontics of University of Athens.

Materials and Methods:
\end{abstract}

The study sample comprised of 100 individuals whose orthodontic treatment had been completed during the period May to October 2010. A questionnaire was designed and piloted before the telephone interviews were carried out. Questions concerned socio-demographic characteristics, reason for seeking care at the Dental School, level of satisfaction with treatment outcome, fees paid for treatment, and various aspects of organisation of care provision, assessed on 1-very dissatisfied to 5-very satisfied Likert type items.

Results:

Satisfaction score was particularly high as far as treatment outcome ( $53 \%$ were "very satisfied" and $31 \%$ were "satisfied"), dentist's response to an emergency ( $81 \%$ were "very satisfied"), and personnel's behavior at initial examination ( $81 \%$ were "very satisfied") were concerned. Factors appearing to require improvement were the waiting time from initial examination to the beginning of treatment, the waiting room and the duration of treatment. Overall satisfaction was found to be significantly associated with total duration of treatment, fees paid by patients, treatment outcome, the behaviour of personnel who conducted first clinical examination, and dentist's response to an emergency. Overall satisfaction was confirmed as the vast majority of patients $(97 \%)$ would recommend the Orthodontic Clinic.

Conclusion:

While the Orthodontics Clinic enjoys overall highly satisfied patients, there is scope for improvement of organizational aspects of care provision like the waiting time between the initial examination and the beginning of treatment, the waiting room and the duration of treatment.

Keywords: Patient, Satisfaction, Orthodontic treatment, Phone interview, Waiting room, Duration.

\begin{tabular}{|l|l|l|l}
\hline Article History & Received: December 23, 2018 & Revised: January 22, 2019 & Accepted: February 09, 2019
\end{tabular}

\section{INTRODUCTION}

The evaluation of patient's satisfaction constitutes a very significant means for the improvement of planning and organization of health care services, and is considered as one of the main ways to estimate the quality of health services [1,2].

While hospital units are increasingly involved in establishing quality assurance and quality assessment practices on a routine basis, dental care providers have mainly been focussing on patient satisfaction, due to the increased evidence that quality of health care is strongly associated with patient satis-

\footnotetext{
* Address correspondence to this author at the Department of Orthodontics, School of Dentistry, University of Athens, Athens, Greece;

E-mail: yiannislyros@hotmail.com
}

faction and compliance, as well as successful treatment outcome $[3,4]$.

Specific tools are developed for the rating of health care users' reported satisfaction level. Furthermore, assessing a number of factors which may influence satisfaction is crucial in setting targets for improvement in order to provide higher quality services.

According to Newsome \& Wright (1999) and Goedhart et al., (1996) [3, 5], health care is accepted as a complex mixture of the emotional, the physical, and the immaterial. In addition, patients' sociodemographic factors, access to dental care, treatment cost and dental surgery facilities have been found to be related with satisfaction. Dentist-patient relationship is also recognised as an additional crucial factor that 
affects the degree of patients' satisfaction. Therefore, it is critical that dentists exhibit communication skills standards at least comparable to those in other health professions, taken into consideration the high levels of dental anxiety, fear and phobia observed among dental patients. The fact that the majority of dental fear cases are reactions to previous stressful dental experiences necessi-tates that dentists should demonstrate knowledges of traumatic dental injuries [6 - 8].

As far as the association of gender and patient satisfaction is concerned, some studies report a strong relationship, while others fail to detect such an association. Studies have also shown that patients do care about the medical office environment and the waiting room, preferring comfortable seats and pleasant music accompaniment $[4,9]$. Patients' expectations have been found to be based on their previous experiences, environment, social background and personality [10 - 13].

Satisfaction with orthodontic treatment is poorly covered in the literature [14]. Females have been found to be more dissatisfied with the appearance of their dentition when compared to males $[15,16]$. It has been shown that malaligned teeth form a greater concern for girls than for boys, and females perceive higher need for orthodontic treatment than males do [17 - 19].

The present study aims to evaluate patients' satisfaction with orthodontic care provided at the Department of Orthodontics (Orthodontic Clinic) of the Dental School of the University of Athens, Greece, as well as to detect factors associated with it.

\section{MATERIALS AND METHODS}

The study was conducted at the Department of Orthodontics, Dental School, University of Athens, Greece, the sample being the last 100 individuals who had completed their orthodontic treatment until October 2010. According to patient records, study sample's effective treatment completion date was between May 2010 and October 2010. The last 100 patients were selected in order to include a sufficiently powered sample size, while decreasing recall bias, given that subjects were those with the most recently completed orthodontic treatment. It is noted that this sample size represents approximately $50 \%$ of the annual turnover of patients. All study subjects were treated by three postgraduate students (trainees orthodontists).

Fieldwork was carried out in October and November 2010 by the same interviewer who conducted all the telephone interviews. Telephone interviews were selected as the most preferable method due to their decreased cost, simplicity and feasibility. During orthodontic treatment, patients had been used to having telephone contacts for issues relating to their treatment.

A purpose made questionnaire for telephone interviews was formulated based on patient's journey in the Orthodontic Clinic from his/her first contact through completion of treatment. The questionnaire consisted of 4 questions on patient's demographic characteristics, and a set of questions investigating various orthodontic care satisfaction dimensions, namely: (1) easiness of arranging appointment for first clinical examination, (2) behaviour of personnel who conducted first clinical examination, (3) waiting time from first clinical examination until start of treatment, (4) opening days and hours of clinic, (5) waiting room environment, (6) interest shown by dentist (trainee orthodontist) and information given to patient during treatment, (7) response by dentist (trainee orthodontist) in case of emergency, (8) total duration of orthodontic treatment, (9) cost (patient fees) of orthodontic treatment, (10) treatment outcome (aesthetic and functional), and (11) overall satisfaction with the Orthodontic Clinic. Level of satisfaction was assessed on Likert type items, the responses ranging from 1 = "Very Dissatisfied" to $5=$ "Very Satisfied", that is, higher score indicates higher level of satisfaction. Additional questions examined the way and reason for choosing the Dental School for care, whether at any time during treatment the patient thought of interrupting treatment and reason for this, and whether the patient would recommend the Orthodontic Clinic to others.

In order to sort out any inconsistencies and assess its time duration, the questionnaire was piloted through telephone on 10 orthodontic patients of the same Clinic who were not otherwise connected to the study. During the main study, the mean duration of the interview was 6 minutes. At the start of the interview, participants were assured for confidentiality and anonymity of responses.

As originally planned and further supported by pilot study findings, patients aged 15-years or older were interviewed themselves, whereas for patients younger than 15-years-old the main proxy (the parent who had most of the contact with the Clinic, escorted most often the child to the Clinic) was interwiewed. The age-related limit of 15 -years was selected due to the fact that children aged 15-years or older are capable of answering questionnaires themselves. Additionally, children younger that 15 -years may did not have clear memories of the past years of treatment.

Data were coded and analysed using the STATA statistical software. Statistical analysis included descriptive statistics, ttest, Chi-square, and ordinal regression (forward stepwise) for investigating the factors associated with satisfaction. The dependent variable was "overall satisfaction with Orthodontic Clinic" and independent variables tested were the 10 items on the various satisfaction dimensions as well as the demographic variables. Furthermore, in order to investigate the factors which may affect the fact that a patient might have thought about interrupting treatment and about recommending the Clinic to others", binary logistic regression analyses were used, the dependent variable being "thinking about interrupting treatment" and "would recommend the Orthodontic Clinic to others" respectively, the independent variables tested being the same 10 items on the various satisfaction dimensions and demographic variables.

\section{RESULTS}

Response rate amounted to $100 \%$. Of the study respondents, 73 were patients themselves and 27 were the proxies (parent) (Table 1).

Of the 100 survey respondents, 41 were males and 59 were females. Proxies tended to be females at a higher percentage 
Table 1. Demographic characteristics of the study sample.

\begin{tabular}{|c|c|c|}
\hline Survey Respondents & n (\%) & - \\
\hline Patients & $73(73.0 \%)$ & - \\
\hline Proxies & $27(27.0 \%)$ & - \\
\hline $\begin{array}{c}\text { Gender } \\
\text { Patients Respondents }^{1,2}\end{array}$ & n (\%) & - \\
\hline Males & $35(47.9 \%)$ & $\begin{array}{c}1: \mathrm{x}^{2}=3.923, \mathrm{~d} . \mathrm{f}=1, \\
p=0.048\end{array}$ \\
\hline Females & $38(52.1 \%)$ & - \\
\hline Patients whose Proxy Responded ${ }^{l}$ & - & - \\
\hline Males & $7(25.9 \%)$ & - \\
\hline Females & $20(74.1 \%)$ & - \\
\hline Proxies Respondents $^{2}$ & - & - \\
\hline Males & $6(22.2 \%)$ & $\begin{array}{c}2: \mathrm{x}^{2}=5.391, \mathrm{~d} . \mathrm{f}=1, \\
p=0.020\end{array}$ \\
\hline Females & $21(77.8 \%)$ & - \\
\hline Age (patients') & mean (s.d) & \\
\hline All Patients & $19.4(8.22)$ & - \\
\hline Males & $20.4(9.51)^{3}$ & - \\
\hline Females & $18.6(7.15)^{3}$ & 3: t-test, $p=0.293$ \\
\hline Patients Respondents & $21.5(8.67)^{4}$ & 4: t-test, $p=0.000$ \\
\hline Males & $21.6(9.98)^{5}$ & - \\
\hline Females & $21.4(7.39)^{5}$ & 5: t-test, $p=0.931$ \\
\hline Patients whose Proxy Responded & $13.6(1.69)^{4}$ & - \\
\hline Males (boys) & $14.4(1.99)^{6}$ & - \\
\hline Females (girls) & $13.4(1.53)^{6}$ & 6: t-test, $p=0.150$ \\
\hline $\begin{array}{c}\text { Education (Respondents') } \\
\text { Patients respondents }\end{array}$ & n (\%) & - \\
\hline Elementary & $1(1.4 \%)$ & - \\
\hline Junior high school & $33(47.1 \%)$ & - \\
\hline High school & $19(27.1 \%)$ & - \\
\hline University & $17(24.3 \%)$ & $\begin{array}{c}7: \mathrm{x}^{2}=9.962, \mathrm{~d} . \mathrm{f}=3, \\
p=0.019\end{array}$ \\
\hline Proxies Respondents $^{7}$ & - & - \\
\hline Elementary & $1(4.0 \%)$ & - \\
\hline Junior high school & $3(12.0 \%)$ & - \\
\hline High school & $12(48.0 \%)$ & - \\
\hline University & $9(36.0 \%)$ & - \\
\hline Missing Values: 5 & - & - \\
\hline
\end{tabular}

than patient respondents $(p<0.05)$ (Table 1). Gender was also recorded for the patients whose proxy participated at the study (consequently gender was recorded for all patients). Thus, as far as patients'gender is concerned, 42 were males and 58 were females.

Age was recorded for patients only, irrespective of whether they themselves or their proxy were the respondents. Mean patient age for all study sample was 19.4 -years-old $(\mathrm{s} . \mathrm{d}=8.22$, $\mathrm{n}=100)$, and was not found to differ significantly $(p=0.293)$ between male patients (mean age $=20.4$, s.d $=9.51, \mathrm{n}=42$ ) and female patients (mean age $=18.6, \mathrm{~s} . \mathrm{d}=7.15, \mathrm{n}=58$ ).

Level of education was recorded for respondents only (irrespective of whether they were the patients themselves or proxies who had responded). It was thus expected, that patient respondents would have a higher percentage of junior high school education (due to their lower age), than proxies respondents $(p<0.05)$ (Table 1).

Of study respondents, $75 \%$ reported that they had been referred for treatment to the Orthodontic Clinic. Of the remaining 25 patients, $21(84 \%)$ said that they had chosen the University Orthodontic Clinic because they considered it as offering better quality of care, or due to lower fees for treatment than those charged by private orthodontists, or because of both reasons. Having been referred in contrast to having chosen at own initiative the University Orthodontic Clinic, and reason for chosing the Clinic were not found to be related to patient's gender, age, or respondent's education.

Results on reported level of satisfaction for each separate dimension of the orthodontic care provision investigated are presented in Table 2 . Of respondents, $81 \%$ said that they were 
Table 2. Distribution of respondents according to level of satisfaction for each dimension.

\begin{tabular}{|c|c|c|c|c|c|c|}
\hline $\begin{array}{c}\text { To What Degree are You Satisfied } \\
\text { with: }\end{array}$ & Very Dissatisfied & Dissatisfied & $\begin{array}{l}\text { Neither Dissatisfied, } \\
\text { Nor Satisfied }\end{array}$ & Satisfied & $\begin{array}{c}\text { Very } \\
\text { Satisfied }\end{array}$ & - \\
\hline- & $\%$ & $\%$ & $\%$ & $\%$ & $\%$ & $\mathbf{n}$ \\
\hline $\begin{array}{l}\text { Response by dentist in case of } \\
\text { emergency }\end{array}$ & - & - & 4 & 15 & 81 & 100 \\
\hline $\begin{array}{l}\text { Behaviour of personnel who conducted } \\
\text { first clinical examination }\end{array}$ & - & - & 6 & 13 & 81 & 100 \\
\hline $\begin{array}{l}\text { Interest shown by dentist and } \\
\text { information } \\
\text { giving to patient during treatment }\end{array}$ & - & 1 & 6 & 15 & 78 & 100 \\
\hline $\begin{array}{l}\text { Treatment outcome (aesthetic and } \\
\text { functional) }\end{array}$ & 1 & - & 2 & 23 & 74 & 100 \\
\hline $\begin{array}{l}\text { Overall satisfaction with the Orthodontic } \\
\text { Clinic }\end{array}$ & 2 & - & 5 & 41 & 52 & 100 \\
\hline $\begin{array}{c}\text { Cost (patient fees) of orthodontic } \\
\text { treatment }\end{array}$ & 1 & 3 & 12 & 31 & 53 & 100 \\
\hline $\begin{array}{l}\text { Easiness of arranging appointment for } \\
\text { first clinical examination }\end{array}$ & - & 3 & 12 & 35 & 50 & 100 \\
\hline Opening days and hours of clinic & 4 & 6 & 18 & 29 & 43 & 100 \\
\hline Total duration of orthodontic treatment & 4 & 8 & 17 & 36 & 35 & 100 \\
\hline $\begin{array}{l}\text { Waiting time from first clinical } \\
\text { examination until start of treatment }\end{array}$ & 3 & 6 & 26 & 35 & 30 & 100 \\
\hline Waiting room environment & 4 & 11 & 25 & 30 & 30 & 100 \\
\hline
\end{tabular}

"very satisfied" with the response by dentist in case of emergency, similar $81 \%$ was the response for the behaviour of personnel who conducted first clinical examination, and $78 \%$ were "very satisfied" with the interest shown by dentist and information giving to patient during treatment. That is, highest level of satisfaction is reported for the three items referring to personnel's professional behaviour and communication. Regarding treatment outcome, $74 \%$ of respondents said that they were "very satisfied". The five items with the lowest "very satisfied" rate were those relating to the organisational aspects of care provision, namely the waiting room environment $(30 \%)$, waiting time from first clinical examination until start of treatment $(30 \%)$, total duration of orthodontic treatment (35\%), opening days and hours of clinic $(43 \%)$, and easiness of arranging appointment for first clinical examination (50\%). Medium level of "very satisfied" rate was found for cost (patient fees) of orthodontic treatment (53\%) and overall satisfaction with the Orthodontic Clinic (52\%).

"Very satisfied" rate was not found to be statistically significantly associated with being a patient respondent or a proxy, gender (neither respondents' nor patients') nor with respondents' education level. Similarly, patients' age did not differ between those reporting being "very satisfied" and those reporting other level of satisfaction.

Of the 100 study participants, 36 answered positively to the question whether at any point they had thought about interrupting their treatment. When these were further asked what was the reason for having such a thought, $16(44.4 \%)$ gave as a reason the duration of treatment, $4(11.1 \%)$ the pain and 2 $(5.6 \%)$ gave as a reason the change of their image. Among the 7 respondents who gave other reasons than the above, the most frequent $(42.8 \%)$ was the distance of the Dental School from their residence.

Having thought about interrupting treatment was not found to be statistically significantly associated with being a patient respondent or a proxy, with gender (neither respondents' nor patients') nor with respondents' education level. Similarly, patients' age did not differ between those reporting being having thought about interrupting treatment and those not having had such a thought.

When study participants were asked whether, based on their experience, they would recommend the Department of Orthodontics to others, the vast majority of them (97\%) answered positively. All 73 patients respondents (100\%) answered positively, while among the 27 proxies respondents, 24 $(88.9 \%)$ gave the same answer $(p=0.020)$. Recommending the University Orthodontic Clinic was not found to be statistically significantly associated with gender (neither respondents' nor patients') or respondents' education level. The three respondents who would not recommend the Clinic were proxies of small children (mean patients age $=13.3$, s.d $=1.53, \mathrm{n}=3$ ) while all those recommending the Clinic represented a mean patients' age of 19.5-years-old $(\mathrm{S} . \mathrm{D}=8.3, \mathrm{n}=97)(p=0.001)$.

Overall satisfaction with the Orthodontic Clinic was found to be positively associated at a statistically significant level with the behaviour of personnel who conducted first clinical examination, the response by dentist in case of emergency, the total duration of orthodontic treatment, the cost (patient fees) of orthodontic treatment, and the treatment outcome (Table 3).

The respondent not having thought about interrupting orthodontic treatment was found to be associated at a statistically significant level with satisfaction with interest shown by dentist and information given to patient during treatment, and with total duration of orthodontic treatment (Table 4). 
Table 3. Factors associated with "overall satisfaction with Orthodontic Clinic" (ordinal regression model).

\begin{tabular}{|c|c|c|c|c|c|c|}
\hline Predictor Variables & Estimate & Standard Error & d.f & $p$ & \multicolumn{2}{|c|}{$\mathbf{9 5 \%}$ C.I } \\
\hline $\begin{array}{c}\text { Behaviour of personnel who } \\
\text { conducted first clinical examination }\end{array}$ & 1.451 & 0.545 & 1 & 0.008 & 0.382 & 2.520 \\
\hline $\begin{array}{c}\text { Response by dentist } \\
\text { in case of emergency }\end{array}$ & 1.828 & 0.641 & 1 & 0.004 & 0.573 & 3.084 \\
\hline $\begin{array}{c}\text { Total duration of } \\
\text { orthodontic treatment }\end{array}$ & 0.791 & 0.325 & 1 & 0.015 & 0.155 & 1.428 \\
\hline $\begin{array}{c}\text { Cost (patient fees) of } \\
\text { orthodontic treatment }\end{array}$ & 0.914 & 0.329 & 1 & 0.005 & 0.269 & 1.559 \\
\hline $\begin{array}{c}\text { Treatment outcome } \\
\text { (aesthetic and functional) }\end{array}$ & 1.595 & 0.503 & 1 & 0.002 & 0.610 & 2.580 \\
\hline
\end{tabular}

McFadden Pseudo R-Square $=0.431$

Table 4. Factors associated with respondents not having thought about interrupting orthodontic treatment (binary logistic regression model).

\begin{tabular}{|c|c|c|c|c|c|}
\hline Predictor Variables & B & Standard Error & d.f & $\boldsymbol{p}$ & $\operatorname{Exp(B)}$ \\
\hline Constant & -6.035 & 2.070 & 1 & 0.004 & 0.002 \\
\hline $\begin{array}{c}\text { Interest shown by dentist and information } \\
\text { giving to patient during treatment }\end{array}$ & 0.982 & 0.460 & 1 & 0.033 & 2.670 \\
\hline Total duration of orthodontic treatment & 0.520 & 0.240 & 1 & 0.030 & 1.682 \\
\hline
\end{tabular}

Model Summary: Nagelkerke R Square: 0.237

Hosmer and Lemeshow Test: $C h i$-square $=4.954$, d.f $=4, p=0.292$

Table 5. Factors associated with respondents' intention to recommend the Orthodontic Clinic to others (binary logistic regression model).

\begin{tabular}{|c|c|c|c|c|c|}
\hline Predictor Variables & B & Standard Error & d.f & $p$ & $\operatorname{Exp}(\mathbf{B})$ \\
\hline Constant & -17.509 & 9.387 & 1 & 0.062 & 0.000 \\
\hline $\begin{array}{c}\text { Treatment outcome } \\
\text { (aesthetic and functional) }\end{array}$ & 2.132 & 1.083 & 1 & 0.049 & 8.432 \\
\hline
\end{tabular}

Model Summary: Nagelkerke R Square: 0.754

Hosmer and Lemeshow Test: Chi-square $=0.077$, d.f $=2, p=0.962$

Recommending the Orthodontic Clinic to other was found to be associated with the treatment outcome (Table 5).

\section{DISCUSSION}

This is the first study ever performed in Greece investigating patients' satisfaction with orthodontic care provision. Thus, comparison of the present study's results with previous investigations is not possible.

In a recent systematic review of the literature by PachêcoPereira et al., factors that were found to be most highly correlated with treatment outcome satisfaction were the final appearance of the teeth [20 - 25], the doctor-staff-patient relationship linked to quality of care and communication [21, $26-31]$, as well as personality traits [14, 32]. Moreover, stability of treatment [33], patient compliance [33], use of orthodontic appliances [29], treatment timing [26, 33, 34] and sex [23, 27] were only slightly associated with patients' satisfaction. However, as it is underlined, women often have higher expectations and are therefore more susceptible to outcome dissatisfaction. Other factors that were also negatively correlated with treatment outcome satisfaction were neuroticism [14], poorer pain management [28], and retention appliances [33, 35]. No evidence was provided supporting an association between age and satisfaction level [14, 28, 36, 37].

Pachêco-Pereira et al., [38], also presented the findings of a literature review, which evaluated satisfaction levels of orthodontic patients who had undergone an orthognathic surgery. Review findings reported that treatment length, sensation of functional impairment and/or dysfunction after surgery were the main factors correlated with dissatisfaction. In contrast, higher level of satisfaction was expressed by patients with skeletal Class I and skeletal Class III malocclusion, patients who underwent bimaxillary surgery, as well as patients who received more information about surgical risks and more care after surgery. Final dentofacial esthetics, perceived social benefits from the outcome and changes in patient self-concept during treatment were also associated with the degree of satisfaction. Additionally, male patients and patients from a lower socioeconomic status were more satisfied, more likely due to lower expectations. The relationship among socioeconomic familial status and needs for dental treatment has been assessed by several studies. Cianetti et al., found that children with low socioeconomic level have a higher prevalence of dental caries and a poorer dental hygiene status. In the same study, it is reported that previous dental attendance does not improve the caries presence, since the dental visits are 
therapeutic and not preventive-prophylactic [39].

In another study conducted by Liao et al., the long term outcomes of bimaxillary surgery were examined in patients with asymmetric skeletal class III deformity, who were treated using surgery-first approach [40]. These findings are in agreement with the results of Pachêco-Pereira et al, mentioned above. In both studies, the importance of evaluating psychological traits of the patients and providing a high quality of care are outlined. According to Liao et al., positive changes in patients' social life and the increase in patients' self-esteem are linked to higher level of satisfaction. In addition to these, communication skills of the team, as well as, providing a realistic prognosis of the surgical result are also recognised as important factors that determine patients' satisfaction.

In a study by Klingenberg et al., (2008), it was found that women patients express higher level of satisfaction for the provided dental services than men [41]. Also, according to Cohen (1996), patients from higher social class present themselves as more satisfied than those of lower social class [42]. However, while certain studies do show that satisfaction is related to gender [43 - 45], age [43, 45] and income [46], there is a number of studies that fail to confirm such a relationship [9, 46 - 48]. According to a recent study conducted by [Feldmann], the factors that most strongly associated with treatment outcome satisfaction were quality of care and attention. On the other hand, factors strongly associated with treatment outcome dissatisfaction were patients' experiences of pain and discomfort during treatment. However, as it is stated in the same article, whereas the median values of treatment outcome satisfaction are high, it is crucial to better understand the reasons why a proportion of patients is dissatisfied [28].

Studies suggest that patients do care about the medical office environment and the waiting room, prefering comfortable seats and pleasant music accompaniment. It is also reported that the experience of small children waiting is improved by increasing the attractiveness of the waiting room of pediatric clinic. The waiting time for dental treatment is a tense process for a lot of patients. However, as long as the duration of waiting time is kept within a reasonable frame, it becomes well acceptable [49 - 53]. In line with these, the present study's findings show that satisfaction with the waiting room and the waiting time up to the beginning of treatment were significantly associated with overall patients' satisfaction. Taking into account that these two aspects exhibited the lowest satisfaction scores, it can be suggested that the Department of Orthodontics should try both to improve the waiting room environment and shorten the waiting time until the patient is called to start treatment, if patients' satisfaction is to be improved.

The time issue appears to be even more important. Duration of treatment was found to have one of the lowest satisfaction scores, and increased duration of treatment was found to increase the possibility that a patient may think of interrupting the treatment. Given that this would impact on both patients' oral health and efficiency of the Department of Orthodontics, it can be suggested that the duration of treatment merits to be given high priority for management. Further research is required to examine whether long duration of treatment is attributed only to the treatment requirements of the clinical conditions treated, or the treatment duration was longer due to organizational mismanagement.

As found by Gürdal et al., (2000), the most important components of satisfaction were the relationship between dentists and patients, organized service system, and scientific ability of dental personnel [9]. Previous research has shown that a well-established relationship and verbal communication between patients and dentists, as well as politeness, and friendliness from the dentist, influence positively the satis-faction which users express. On the contrary, low degree of communication of health care provider and patient, in combination with stress of patients during treatment, is related to low rates of satisfaction. Thus, it is proposed that health care providers are educated in communication skills [54 - 59]. The present study corroborates the above literature. Dentists' interest and information giving to patient by himself was found to be significantly associated with the possibility that a patient may think of interrupting the treatment. Furthermore, dentists' interest and information giving to patient by himself, as well as dentist's response on emergency were found to be significantly associated with patients' overall satisfaction. The fact that these two factors were found to have the highest satisfaction scores ( $78 \%$ and $81 \%$ respectively were "very satisfied") suggests that the Department of Orthodontics is performing well on this aspect.

According to a study by Abrams et al., (1986) the exercise of dentistry with technical dexterity does not convince the patient that he has received high quality dental care, and, consequently, dentists should not overlook human and psychological factors of care and should remember that these factors are fundamental components of quality in dental treatment [60].

Regarding clinical outcome of dental treatment, functionality and esthetics, no correlation with satisfaction has been identified. Based on a systematic review aiming to estimate the stability of orthodontic result and patients' satisfaction at least five years after treatment, firm conclusions were difficult to be deduced [61]. Our results suggest that the treatment outcome is significantly associated with patients' overall satisfaction. This coupled with the finding that patients reported very high satisfaction rate $(74 \%$ were "very satisfied" and $23 \%$ were "satisfied") with treatment outcome indicates that the Department of Orthodontics performs well in this aspect and has to continue to do so.

Regarding the treatment fees charged by the Department of Orthodontics to patients, it has to be noted that these are rather low when compared to the prevailing orthodontic market prices. Thus, a considerably high satisfaction rate $(53 \%$ were "very satisfied" and 31\% were "satisfied") with the fees paid and their significant association with satisfaction with overall treatment suggest that orthodontic patients treated at the Athens Dental School perceive that they receive good value for money. Similar findings can be found in the previous literature, where dental treatment fees charged are related to patient satisfaction with dental care. (Stahlnacke et al., 2007) Kress and Silversin (1987) and Barnes (1985) found that treatment cost is used as an indicator of quality by the patients $[52,62,63]$. When 
patients consider they have received high quality services, they justify the increased prices and opposite.

As far as long-term patient satisfaction is concerned, a higher degree of satisfaction has been shown when patients are questioned at least 5 years after the end of orthodontic treatment [Maia]. From a long-term perspective, stability of the orthodontic treatment, regardless of the initial occlusal condition or the final result, is weakly correlated with patient satisfaction.No association was found between gender, age, extraction for orthodontic reasons and the amount of treatment time with long-term patient satisfaction [35].

\section{CONCLUSION}

Patients who have been treated at the Department of Orthodontics, Dental School, University of Athens, Greece report high level of satisfaction with care. Overall satisfaction is also confirmed by the fact that the vast majority of them would recommend the Orthodontic Clinic.

Satisfaction appears particularly high as far as the treatment outcome, the response of the dentist to an emergency and behavioural and communication aspects are concerned. However, the factors which appear to require improvement are the waiting time from initial examination to the beginning of treatment, the waiting room and the duration of treatment. According to the existing literature, it is confirmed that the extended duration of treatment constitutes the main complaint of dental and particularly orthodontic patients $[9,34]$.

Finally, the present study may constitute the spark for further investigation in the field of quality aspects of orthodontic care.

\section{ETHICS APPROVAL AND CONSENT TO PARTICI- PATE}

Not applicable

\section{HUMAN AND ANIMAL RIGHTS}

No animals/humans were used for studies that are the basis of this research.

\section{CONSENT FOR PUBLICATION}

Informed consent was obtained from the participants prior to being enrolled in the study.

\section{FUNDING}

None.

\section{CONFLICT OF INTEREST}

The authors declare no conflict of interest, financial or otherwise.

\section{ACKNOWLEDGEMENTS}

Declared none.

\section{REFERENCES}

[1] Ford RC, Bach SA, Fottler MD. Methods of measuring patient satisfaction in health care organizations. Health Care Manage Rev 1997; 22(2): 74-89. [http://dx.doi.org/10.1097/00004010-199704000-00009] [PMID: 9143 904]

[2] Tountas Y, Lopatatzidis A, Houliara L. Degree of satisfaction among IKA beneficiaries concerning primary health care services offered. Arch Hellenic Med 2003; 20(5): 497-503.

[3] Newsome PRH, Wright GH. A review of patient satisfaction: 1. Concepts of satisfaction. Br Dent J 1999; 186(4 Spec No): 161-5. [PMID: 10205951]

[4] Ntabaye MK, Scheutz F, Poulsen S. Patient satisfaction with emergency oral health care in rural Tanzania. Community Dent Oral Epidemiol 1998; 26(5): 289-95.

[http://dx.doi.org/10.1111/j.1600-0528.1998.tb01963.x] [PMID: 9792 119]

[5] Goedhart H, Eijkman MAJ, ter Horst G. Quality of dental care: The view of regular attenders. Community Dent Oral Epidemiol 1996; 24(1): $28-31$.

[http://dx.doi.org/10.1111/j.1600-0528.1996.tb00808.x] [PMID: 8833 511]

[6] Asl AN, Shokravi M, Jamali Z, Shirazi S. Barriers and drawbacks of the assessment of dental fear, dental anxiety and dental phobia in children: A critical literature review. J Clin Pediatr Dent 2017; 41(6): 399-423.

[http://dx.doi.org/10.17796/1053-4628-41.6.1] [PMID: 28937891]

[7] Cianetti S, Lombardo G, Lupatelli E, et al. Dental fear/anxiety among children and adolescents. A systematic review. Eur J Paediatr Dent 2017; 18(2): 121-30.

[PMID: 28598183]

[8] Alyasi M, Al Halabi M, Hussein I, Khamis AH, Kowash M. Dentists' knowledge of the guidelines of traumatic dental injuries in the United Arab Emirates. Eur J Paediatr Dent 2018; 19(4): 271-6. [http://dx.doi.org/10.23804/ejpd.2018.19.04.4] [PMID: 30567442]

[9] Gürdal P, Cankaya H, Onem E, Dinçer S, Yílmaz T. Factors of patient satisfaction/dissatisfaction in a dental faculty outpatient clinic in Turkey. Community Dent Oral Epidemiol 2000; 28(6): 461-9. [http://dx.doi.org/10.1034/j.1600-0528.2000.028006461.x] [PMID: 11106019]

[10] Freeman R. Barriers to accessing dental care: Patient factors. Br Dent J 1999; 187(3): 141-4. [PMID: 10481365]

[11] Collett HA. Influence of dentist-patient relationship on attitudes and adjustment to dental treatment. J Am Dent Assoc 1969; 79(4): 879-84. [http://dx.doi.org/10.14219/jada.archive.1969.0258] [PMID: 5266073]

[12] Freeman R. Barriers to accessing and accepting dental care. Br Dent J 1999; 187(2): 81-4. [PMID: 10464987]

[13] Lahti S, Tuutti H, Hausen H, Kääriäinen R. Dentist and patient opinions about the ideal dentist and patient:Developing a compact questionnaire. Community Dent Oral Epidemiol 1992; 20(4): 229-34. [http://dx.doi.org/10.1111/j.1600-0528.1992.tb01722.x] [PMID: 1526 110]

[14] Al-Omiri MK, Abu Alhaija ES. Factors affecting patient satisfaction after orthodontic treatment. Angle Orthod 2006; 76(3): 422-31. [PMID: 16637722]

[15] Shaw WC. Factors influencing the desire for orthodontic treatment. Eur J Orthod 1981; 3(3): 151-62.

[http://dx.doi.org/10.1093/ejo/3.3.151] [PMID: 6943029]

[16] Sheats RD, McGorray SP, Keeling SD, Wheeler TT, King GJ. Occlusal traits and perception of orthodontic need in eighth grade students. Angle Orthod 1998; 68(2): 107-14. [PMID: 9564419]

[17] Gosney MBE. An investigation into some of the factors influencing the desire for orthodontic treatment. Br J Orthod 1986; 13(2): 87-94. [http://dx.doi.org/10.1179/bjo.13.2.87] [PMID: 3456796]

[18] Bergius M, Berggren U, Kiliaridis S. Experience of pain during an orthodontic procedure. Eur J Oral Sci 2002; 110(2): 92-8. [http://dx.doi.org/10.1034/j.1600-0722.2002.11193.x] [PMID: 1201 3568]

[19] Wheeler TT, McGorray SP, Yurkiewicz L, Keeling SD, King GJ. Orthodontic treatment demand and need in third and fourth grade schoolchildren. Am J Orthod Dentofacial Orthop 1994; 106(1): 22-33. [http://dx.doi.org/10.1016/S0889-5406(94)70017-6] [PMID: 8017346]

[20] Uslu O, Akcam MO. Evaluation of long-term satisfaction with orthodontic treatment for skeletal class III individuals. J Oral Sci 2007; 49(1): 31-9.

[http://dx.doi.org/10.2334/josnusd.49.31] [PMID: 17429180]

[21] Anderson LE, Arruda A, Inglehart MR. Adolescent patients' treatment motivation and satisfaction with orthodontic treatment. Do possible 
selves matter? Angle Orthod 2009; 79(5): 821-7. [http://dx.doi.org/10.2319/120708-613.1] [PMID: 19705953]

[22] Oliveira PG, Tavares RR, Freitas JC. Assessment of motivation, expectations and satisfaction of adult patients submitted to orthodontic treatment. Dental Press J Orthod 2013; 18(2): 81-7.

[http://dx.doi.org/10.1590/S2176-94512013000200018] [PMID: 2391 6436]

[23] Birkeland K, Bøe OE, Wisth PJ. Relationship between occlusion and satisfaction with dental appearance in orthodontically treated and untreated groups. A longitudinal study. Eur J Orthod 2000; 22(5): 509-18.

[http://dx.doi.org/10.1093/ejo/22.5.509] [PMID: 11105407]

[24] Espeland LV, Stenvik A. Perception of personal dental appearance in young adults: relationship between occlusion, awareness, and satisfaction. Am J Orthod Dentofacial Orthop 1991; 100(3): 234-41. [http://dx.doi.org/10.1016/0889-5406(91)70060-A] [PMID: 1877547]

[25] Bennett ME, Tulloch JF, Vig KW, Phillips CL. Measuring orthodontic treatment satisfaction: Questionnaire development and preliminary validation. J Public Health Dent 2001; 61(3): 155-60.

[http://dx.doi.org/10.1111/j.1752-7325.2001.tb03383.x] [PMID: 1160 3319]

[26] Keles F, Bos A. Satisfaction with orthodontic treatment. Angle Orthod 2013; 83(3): 507-11.

[http://dx.doi.org/10.2319/092112-754.1] [PMID: 23181757]

[27] Bos A, Vosselman N, Hoogstraten J, Prahl-Andersen B. Patient compliance: A determinant of patient satisfaction? Angle Orthod 2005; 75(4): 526-31 [PMID: 16097220]

[28] Feldmann I. Satisfaction with orthodontic treatment outcome. Angle Orthod 2014; 84(4): 581-7.

[http://dx.doi.org/10.2319/093013-710.1] [PMID: 24423202]

[29] Bergström K, Halling A, Wilde B. Orthodontic care from the patients' perspective: Perceptions of 27-year-olds. Eur J Orthod 1998; 20(3): 319-29.

[http://dx.doi.org/10.1093/ejo/20.3.319] [PMID: 9699410]

[30] Fernandes LM, Espeland L, Stenvik A. Patient-centered evaluation of orthodontic care: A longitudinal cohort study of children's and parents' attitudes. Am J Orthod Dentofacial Orthop 1999; 115(3): 227-32.

[http://dx.doi.org/10.1016/S0889-5406(99)70322-7] [PMID: 1006 6968]

[31] Mascarenhas AK, Vig K, Joo BH. Parents' satisfaction with their child's orthodontic care: A comparison of orthodontists and pediatric dentists. Pediatr Dent 2005; 27(6): 451-6. [PMID: 16532884]

[32] Barker MJ, Thomson WM, Poulton R. Personality traits in adolescence and satisfaction with orthodontic treatment in young adulthood. Aust Orthod J 2005; 21(2): 87-93.

[PMID: 16429863]

[33] Mollov ND, Lindauer SJ, Best AM, Shroff B, Tufekci E. Patient attitudes toward retention and perceptions of treatment success. Angle Orthod 2010; 80(4): 468-73.

[http://dx.doi.org/10.2319/102109-594.1] [PMID: 20482350]

[34] Riedmann T, Georg T, Berg R. Adult patients' view of orthodontic treatment outcome compared to professional assessments. J Orofac Orthop 1999; 60(5): 308-20

[http://dx.doi.org/10.1007/BF01301244] [PMID: 10546414]

[35] Maia NG, Normando D, Maia FA, Ferreira MA, do Socorro Costa Feitosa Alves M. Factors associated with long-term patient satisfaction. Angle Orthod 2010; 80(6): 1155-8.

[http://dx.doi.org/10.2319/120909-708.1] [PMID: 20677969]

[36] Bos A, Hoogstraten J, Prahl-Andersen B. Attitudes towards orthodontic treatment: A comparison of treated and untreated subjects. Eur J Orthod 2005; 27(2): 148-54

[http://dx.doi.org/10.1093/ejo/cjh071] [PMID: 15817621]

[37] Pachêco-Pereira C, Pereira JR, Dick BD, Perez A, Flores-Mir C. Factors associated with patient and parent satisfaction after orthodontic treatment: A systematic review. Am J Orthod Dentofacial Orthop 2015; 148(4): 652-9.

[http://dx.doi.org/10.1016/j.ajodo.2015.04.039] [PMID: 26432321]

[38] Pachêco-Pereira C, Abreu LG, Dick BD, De Luca Canto G, Paiva SM, Flores-Mir C. Patient satisfaction after orthodontic treatment combined with orthognathic surgery: A systematic review. Angle Orthod 2016; 86(3): 495-508.

[http://dx.doi.org/10.2319/040615-227.1] [PMID: 26313228]

[39] Cianetti S, Lombardo G, Lupatelli E, et al. Dental caries, parents educational level, family income and dental service attendance among children in Italy. Eur J Paediatr Dent 2017; 18(1): 15-8 [PMID: 28494596]

[40] Liao YF, Chen YF, Yao CF, Chen YA, Chen YR. Long-term outcomes of bimaxillary surgery for treatment of asymmetric skeletal class III deformity using surgery-first approach. Clin Oral Investig 2018. Epub ahead of print

[http://dx.doi.org/10.1007/s00784-018-2603-y] [PMID: 30155572]

[41] Klingenberg A, Walther W, Dörfer CE, Szecsenyi J. Patient evaluation of dental care. Results of a written patient survey in dental practices. Gesundheitswesen 2008; 70(8-9): 525-31.

[http://dx.doi.org/10.1055/s-2008-1077061] [PMID: 18785098]

[42] Cohen G. Age and health status in a patient satisfaction survey. Soc Sci Med 1996; 42(7): 1085-93.

[http://dx.doi.org/10.1016/0277-9536(95)00315-0] [PMID: 8730914]

[43] Newsome PRH, Wright GH. Patient Management: A review of patient satisfaction: Dental patient satisfaction: An appraisal of recent literature. Br Dent J 1999; 186: 166-70.

[PMID: 10205952]

[44] Rankin JA, Harris MB. Patients' preferences for dentists' behaviors. J Am Dent Assoc 1985; 110(3): 323-7.

[http://dx.doi.org/10.14219/jada.archive.1985.0349] [PMID: 3858344]

[45] Lahti S, Tuutti H, Hausen H, Käärlänen R. Patients' expectations of an ideal dentist and their views concerning the dentist they visited: do the views conform to the expectations and what determines how well they conform? Community Dent Oral Epidemiol 1996; 24(4): 240-4.

[http://dx.doi.org/10.1111/j.1600-0528.1996.tb00852.x] [PMID: 8871 030]

[46] Tuominen R, Tuominen M. Satisfaction with dental care among elderly Finnish men. Community Dent Oral Epidemiol 1998; 26(2): 95-100.

[http://dx.doi.org/10.1111/j.1600-0528.1998.tb01934.x] [PMID: 9645 402]

[47] Tuominen R, Paunio I. Utilization of oral health services among older adults in Finland: An epidemiologic and econometric analysis. Gerodontics 1987; 3(5): 215-8. [PMID: 3127262]

[48] Berg E, Johnsen TB, Ingebretsen R. Social variables and patient acceptance of complete dentures. A study of patients attending a dental school. Acta Odontol Scand 1985; 43(4): 199-203.

[http://dx.doi.org/10.3109/00016358509046499] [PMID: 3864338]

[49] Andrus D, Buchheister J. Major factors affecting dental consumer satisfaction. Health Mark Q 1985; 3(1): 57-68. [http://dx.doi.org/10.1300/J026v03n01 08] [PMID: 10273809]

[50] Pati D, Nanda U. Influence of positive distractions on children in two clinic waiting areas. HERD 2011; 4(3): 124-40.

[http://dx.doi.org/10.1177/193758671100400310] [PMID: 21866509]

[51] Gibler J, Nyswonger G, Engel AM, Grannan K, Welling R. Improving satisfaction ratings of surgical patients from referral to follow-up in the faculty medical center clinic. J Surg Educ 2011; 68(5): 360-4.

[http://dx.doi.org/10.1016/j.jsurg.2011.03.008] [PMID: 21821213]

[52] Ståhlnacke K, Söderfeldt B, Unell L, Halling A, Axtelius B. Patient satisfaction with dental care in one Swedish age cohort. Part II--What affects satisfaction. Swed Dent J 2007; 31(3): 137-46. [PMID: 17970170]

[53] Tuominen R, Eriksson AL. Patient experiences during waiting time for dental treatment. Acta Odontol Scand 2012; 70(1): 21-6. [http://dx.doi.org/10.3109/00016357.2011.575079] [PMID: 21504269]

[54] Corah NL, O'Shea RM, Bissell GD. The dentist-patient relationship: perceptions by patients of dentist behavior in relation to satisfaction and anxiety. J Am Dent Assoc 1985; 111(3): 443-6.

[http://dx.doi.org/10.14219/jada.archive.1985.0144] [PMID: 3862704]

[55] Gale EN, Carlsson SG, Eriksson A, Jontell M. Effects of dentists' behavior on patients' attitudes. J Am Dent Assoc 1984; 109(3): 444-6. [http://dx.doi.org/10.14219/jada.archive.1984.0413] [PMID: 6592232]

[56] Moore P, Vargas A, Núñez S, Macchiavello S. A study of hospital complaints and the role of the doctor-patient communication. Rev Med Chil 2011; 139(7): 880-5.

[http://dx.doi.org/10.4067/S0034-98872011000700008] [PMID: 2205 1825]

[57] Schouten BC, Eijkman MA, Hoogstraten J. Dentists' and patients' communicative behaviour and their satisfaction with the dental encounter. Community Dent Health 2003; 20(1): 11-5. [PMID: 12688598]

[58] Sinha PK, Nanda RS, McNeil DW. Perceived orthodontist behaviors that predict patient satisfaction, orthodontist-patient relationship, and patient adherence in orthodontic treatment. Am J Orthod Dentofacial Orthop 1996; 110(4): 370-7. 
[http://dx.doi.org/10.1016/S0889-5406(96)70037-9] [PMID: 8876486]

[59] Veldhuis B, Schouten BC. The relationship between communication styles of dentists and the satisfaction of their patients. Ned Tijdschr Tandheelkd 2003; 110(10): 387-90

[PMID: 14606244]

[60] Abrams RA, Ayers CS, Vogt Petterson M. Quality assessment of dental restorations: a comparison by dentists and patients. Community Dent Oral Epidemiol 1986; 14(6): 317-9.

[http://dx.doi.org/10.1111/j.1600-0528.1986.tb01081.x] [PMID: 3466 $756]$
[61] Bondemark L, Holm AK, Hansen K, et al. Long-term stability of orthodontic treatment and patient satisfaction. A systematic review. Angle Orthod 2007; 77(1): 181-91.

[http://dx.doi.org/10.2319/011006-16R.1] [PMID: 17029533]

[62] Kress GC Jr, Silversin JB. The role of dental practice characteristics in patient satisfaction. Gen Dent 1987; 35(6): 454-7. [PMID: 3481729]

63] Barnes NG. Open wide: an examination of how patients select and evaluate their dentist. Health Mark Q 1985; 3(1): 49-56. [http://dx.doi.org/10.1300/J026v03n01_07] [PMID: 10273808]

\section{(C) 2019 Lyros et al.}

This is an open access article distributed under the terms of the Creative Commons Attribution 4.0 International Public License (CC-BY 4.0), a copy of which is available at: (https://creativecommons.org/licenses/by/4.0/legalcode). This license permits unrestricted use, distribution, and reproduction in any medium, provided the original author and source are credited. 